\title{
Municipal management and geo-hydrological aspects of importance in the potable water supply of Lindley
}

EJNEALER ${ }^{1}$ AND WE BERTRAM ${ }^{2}$

\section{Abstract}

When the South African Government in 1998 re-demarcated its 283 municipalities so that they completely cover the country in a "wall-to-wall" manner, their main focus was on growing local economies and maintaining the provision of an increased number of diverse and more complex basic municipal services to new geographical areas consisting of millions of citizens who might previously had been neglected.

In most of the instances the newly established and merged municipalities were demarcated according to geographical aspects inherited from the previous political dispensation, historical municipal areas and magisterial district farm names. The fact that these municipal government jurisdictions for the purpose of improving co-operative municipal- and integrated water resources management (IWRM), in most instances do not correspond with environmental and physical land features such as the demarcated surface water (rivers) drainage regions' boundaries, could lead to the ineffective, inefficient and non-economic municipal management of water, sanitation and environmental services.

The aforementioned is a case with reference to water services management in the Free State Province town of Lindley located in the Vals River catchment and the Nketoana Local Municipality's area of jurisdiction.

An extensive literature review, the use and study of geographic tools such as maps, orthophotos and information data bases, as well as two field visits to the area, enabled the researchers to identify the essential geographical, geo-hydrological and municipal management aspects of importance for the potable water service providers and managers in the Lindley municipal area.

The researchers argue that effective trans-boundary municipal management through simunye-type co-operative governance and IWRM must be facilitated in the Vals River surface water catchment between the respective local- and district municipalities for the benefit of the Lindley, Arlington, Steynsrus and Kroonstad communities.

Key words: Municipality; co-operative governance; integrated water resources management; surface water catchment; municipal area; geo-hydrology; municipal governance; potable water.

\section{Introduction}

When the South African Government in 1998 re-demarcated its 283 municipalities (RSA, 1998: Section 21) in such a manner that they cover the whole country, their main focus has been the facilitation of effective and sustainable developmental municipal management. Their main aim has been the improvement of basic municipal services such as formalised municipal basic services (e.g. safe potable water, effective refuse removal and environmental health) to

1. Prof. EJ Nealer, Prof Eric Nealer, Public Administration \& Management, UNISA, Pretoria. Email correspondence: nealee1@unsa.ac.za.

2. Department of Water Affairs, Pretoria. 
all the residents of the newly demarcated municipal areas. Some of the geographical areas consist of millions of citizens who had previously been and possibly now, neglected.

In most instances the newly established and merged municipalities were demarcated according to geographical aspects inherited from the previous political dispensation, historical municipal areas and magisterial district farm names. Fuggle and Rabie (2005:315) are of the opinion that the surface water catchment regions, demarcated by Department of Water Affairs (DWA) according to the surface water divides, should be utilised as area delimiter for geographical planning purposes. They also pointed out that the omission of this planning tool in the demarcation process of the new municipal areas of a developing South Africa could lead to ineffective, inefficient and non-economic municipal management of basic services.

The researchers are of the opinion that some of the major reasons for the unrests, protests and general dissatisfaction with basic service delivery in many municipal areas is due to the lack of co-operative governance regarding effective basic public services delivery in most of the municipal areas. Furthermore, with reference to water services, there are no signs of integrated water resources management (IWRM) being realised in the areas.

In order to prove this hypothesis, a typical Northern Free State municipal area (Lindley) was identified. A literature review, maps study, and field visits to the town area were deployed to identify essential geographical, municipal management and geo-hydrological aspects of importance for the facilitation of developmental local governance in the Lindley area. See Figure 1 for a locality map of the town and the Vals River surface water catchment area.

Subsequently, conclusions were drawn on the nature and extent of basic water services and its management in the Lindley municipal area. Based on the aforementioned, recommendations are also made on the rendering of public service delivery by the local government institution in its geographical area of responsibility.

\section{Background and problem statement}

Lindley is a small northern Free State Province town located on the southern bank of the Vals River. A weir built across the river next to the current water purification works has created a five-kilometer stretch of deep water that is ideal for angling, boating and swimming. The settlement was established on the farm Brandhoek in 1875 and proclaimed a town in 1878. The town was named after Reverend Daniel Lindley, an American Presbyterian missionary, regarded as the first missionary of the Great Trek (1836) (Lindley, 2007: Online).

Tourist attractions in Lindley include a British memorial in the local cemetery for British soldiers who died on 31 May 1900 at Yeomanry Hills, prehistoric stone huts of the original inhabitants of the area as well as a miniature replica of the Dutch Reformed Church that was erected in 1928 in memory of those who died during the Second Anglo-Boer War.

Lindley, together with the towns of Reitz, Arlington and Petrus Steyn, has since the promulgation of the Local Government: Municipal Demarcation Act 27 of 1998 and the Local Government: Municipal Systems Act 32 of 2000, formed part of the Nketoana Local Municipality (head office located in Reitz) which is situated in the Thabo Mofutsanyane District Municipality's geographical area of responsibility (head office located in Phuthaditjhaba). Lindley is the first town located close to the head waters and source of the Vals River catchment. See Figure 1 for some geographical information on the location of this 
surface water catchment and Lindley in relation to, for example, Steynsrus and Kroonstad which are located further downstream and which are also dependent on the river source:

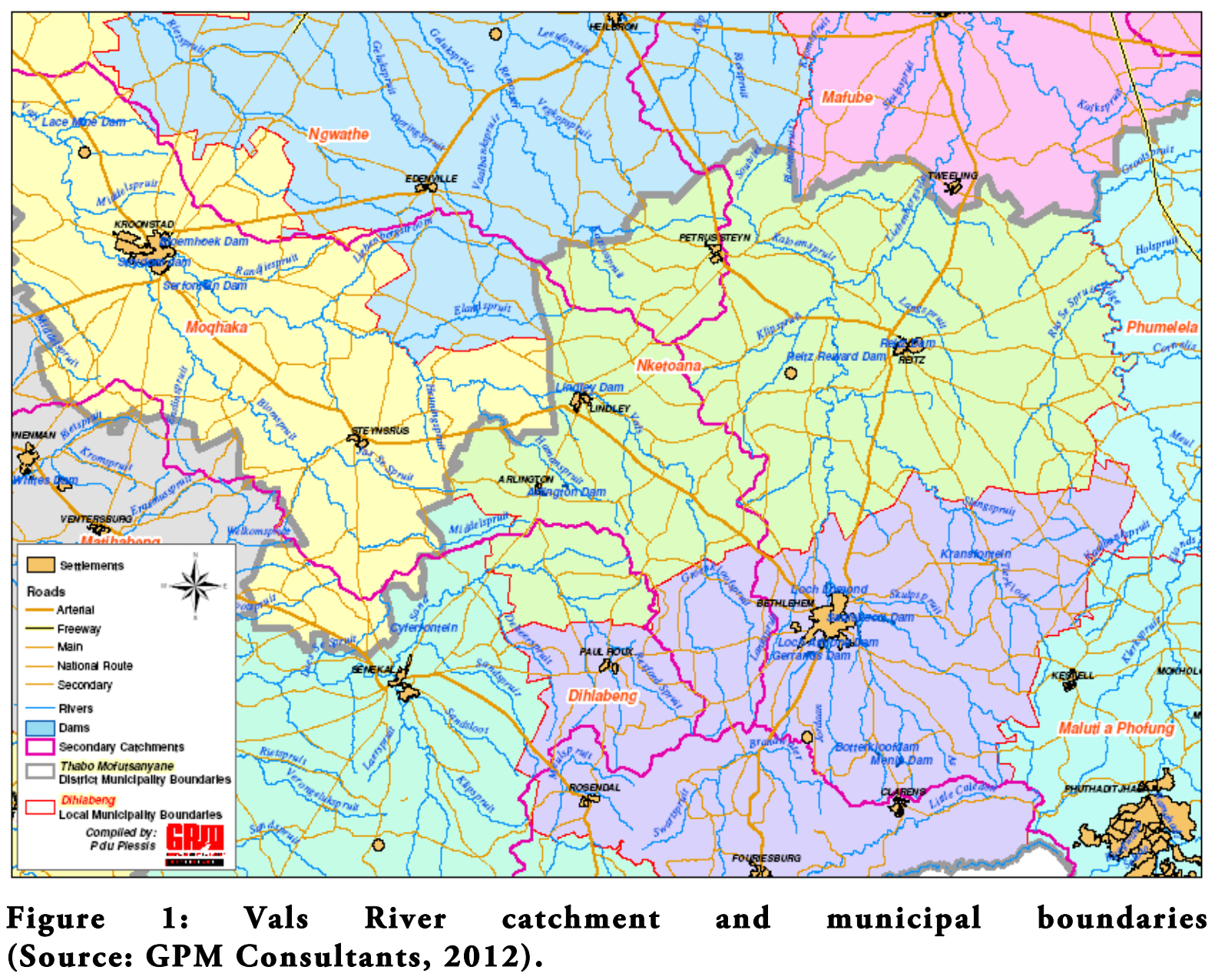

Figure 1 reveals that the demarcating boundary between the Thabo Mofutsanyane and Fezile Dabi district municipalities does not take into account any natural features such as mountain ranges, surface water catchments or major landmarks. It merely follows the historical demarcation of magisterial districts and topo-cadastral farms. This method of identification and demarcation of the current municipalities' geographical area of responsibility tendency has been a common approach utilised with the re-demarcation of municipal areas since 2000 .

Over the past eight years, the residents in towns such as Lindley, Arlington, Senekal, Steynsrus and Kroonstad in the northern Free State Province have experienced improved basic municipal services such as on-site drinking water, water-based sanitation and the fitting of solar heating geysers in thousands of newly established households. These positive changes have been as a result of, inter alia, the ANC-led government's attempts to facilitate effective developmental local government (promotion of economic and social development of the society through democratisation and transformation of local governance (Van der Waldt et al., 2014:21) and the Masibambane water services sector support programme in the Free State Province (DWAF, 2005: Online). Consequently, the residents' basic needs became sophisticated. Unfortunately, this has taken place in areas which are hampered by regular droughts, where the rivulets and "spruite" in the province have stopped flowing, and the groundwater levels are dropping which are evidence of the termination of spring-flows in the area (Brits, 2012: Interview). 
The purpose of this research was to obtain a "snapshot" of the nature and extent of potable water supply in Lindley and the general municipal management of the particular public water related services such as water purification, storm water collection and sewage treatment. In other words, the origin of the area's drinking water, the management thereof, and the destiny of the used water were identified and described as research foci in an attempt to deploy improved municipal management and co-operative governance to bring about and facilitate an effective integrated water resources management (IWRM). Thompson (2006:162) defines IWRM as "a process which promotes the co-ordinated development and management of water, land and related resources in order to maximise the resultant economic and social welfare in an equitable manner without compromising the sustainability of vital ecosystems".

\section{Specific municipal management aspects of importance}

Lindley's old town area has a small central business district on the eastern side of the Senekal to Petrus Steyn tarred road (R707) which is surrounded by the urban free-standing housing of a typical Free State town. Approximately 372 Municipal serviced residential stands for businesses and 750 houses for the residents have been catered for in this area.

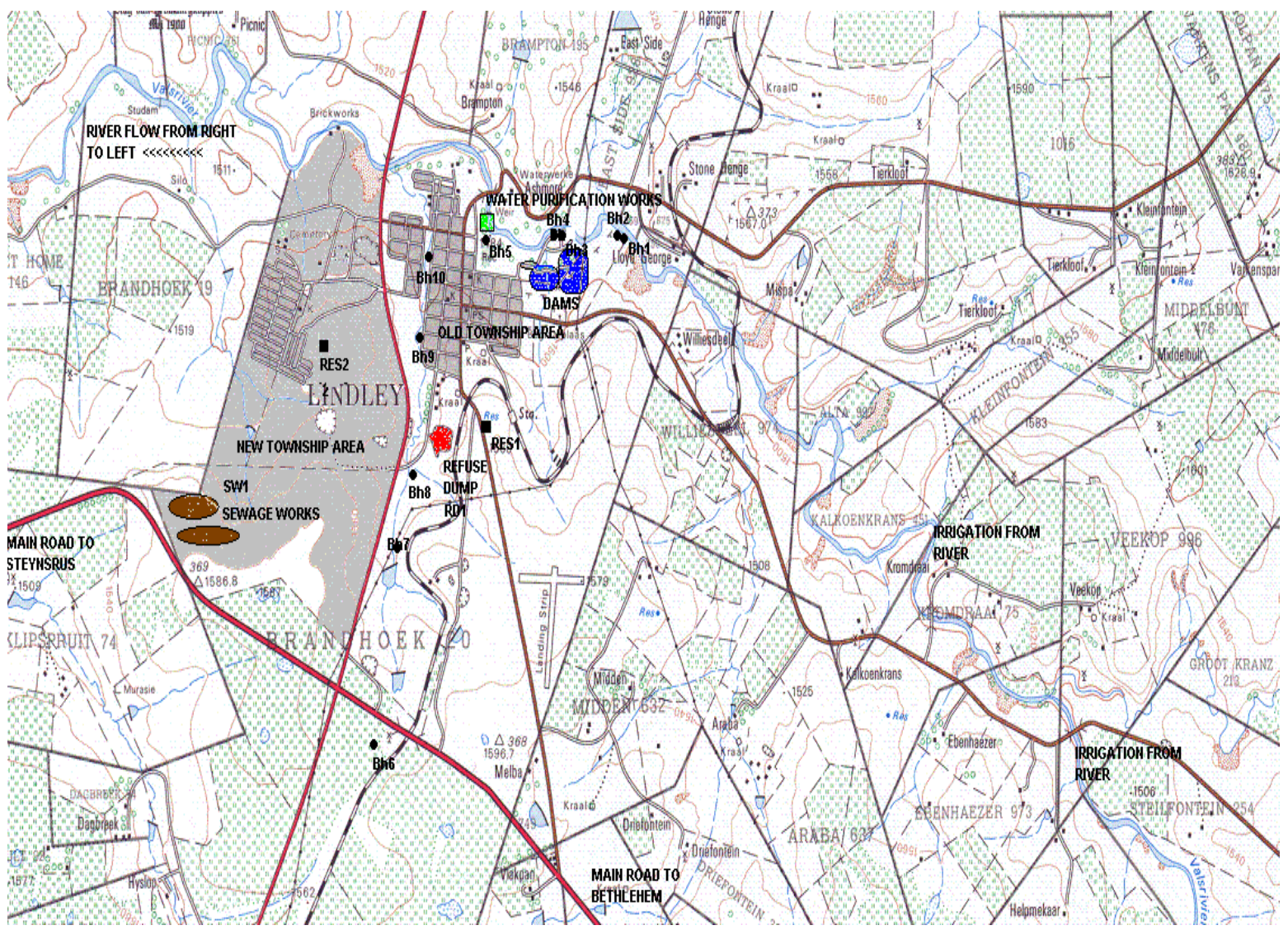

Figure 2: Lindley locality map (Source: Department of Land Affairs, 1987; Additions by authors, 2012).

Key to the map:

BH1 to BH10: Groundwater abstraction boreholes of Municipality

RES1 to RES2: Water reservoir

DAM1 and DAM2: Water storage dams next to Vals River

SW1: Sewage works

RD1: Refuse dumpsite

New township: Ntha with services potable water and sanitation stands 
The new town area (Ntha) is situated on the western side of the Senekal to Petrus Steyn tarred road (R707) and expands to the Kroonstad and Bethlehem main road (R76). In this area the Municipality caters for 3318 serviced residential stands for approximately 30000 residents - approximately 7 persons per home. An additional 970 stands with limited municipal services are also catered for (Housing department, 2012). See Figure 2 for an exposition of the expanding Town area and its development:

Lindley has a regional Town Office: Nketoana Local Municipality which is situated in the centre of town and staffed with municipal officials responsible for roads, storm water, potable water, sanitation and financial issues. The Office is managed from the Nketoana Local Municipality's office in Reitz (69 km away) where public policy implementation instructions, monitoring, reporting and evaluation are managed through effective communication media.

Through, for example, the aforementioned organised structure, a municipality is expected to share and benefit from effective co-operative governance from the involved actors (roleplayers, stakeholders and influential individuals). This entails the incorporation of the collective and integrated synergies between the embedded environmental, economic viability (including technology), and social equity (including culture and politics) systems which are underpinned by or grounded in the facilitating system of governance and specifically, cooperative governance in a holistic quest for effective public decision-making and policy implementation (Glasson \& Wood, 2009).

Integrating environmental considerations into sectoral policy and activities remains a key challenge for effective co-operative governance as a vehicle to facilitate sustainable development. Civil society enterprises and public sector institutions also need to be identified, strengthened and linked in synergetic partnerships to enhance their ability to, inter alia, monitor government spheres and to interact on a more equal footing with role-players such as the private sector and representative stakeholders from affected communities. However, the three sectors require considerable education and awareness-raising with regard to an understanding of sustainable development and the implications for more effective public policy making and implementation.

A significant aspect to the aforementioned objectives of co-operative governance is the existence of effective organisational arrangements (internal and external) of which two-way communication is first and foremost. This should lead to higher levels of visibility, transparency, access and willingness by committed actors to become involved and participate actively in holistic and synergised group attempts of service delivery and sustainable development per se (Nealer \& Naude, 2011). Research has shown that it was, and still is, difficult to work collaboratively and the efforts required to implement co-operative governance are problematic.

\section{Specific geo-hydrological management aspects of importance}

Geologically, the Lindley area is predominantly underlain by sandstones of the Beaufort Group. This Group forms the upper layers of the Karoo Super Group (SACS, 1980). The groundwater conditions of any particular area depend mainly on the geology. This aspect will be discussed followed by its relevance to the geo-hydrology of the area.

The basin in which the Karoo Super Group was deposited started developing about 300 million years ago when the area was in the grip of an Ice Age - the deposits formed during this period are called the Dwyka Group. As the ice receded, an extreme wet climate ensued and the plant material, which later became the extensive coal deposits, was laid down and the 
rocks formed the Ecca Group. The climate started drying and the Beaufort Group was deposited. Deposits formed under such a climate are coarse grained which can be seen in the soils in the vicinity of Lindley. The sand grains are not bound strongly. This is observed by how easily the rocks erode.

A further drying out of the climate led to Aeolian deposits called the Clarens Formation. The most spectacular place where this formation can now be observed is the Golden Gate National Park in the Eastern Free State.

The deposits of the Karoo Super Group were ended by massive outflows of lava, which built the Lesotho Highlands. Together with this outpouring there were also many intrusions of molten rock into the rocks of the Karoo Super Group. The Ecca Group was prone to these molten dolorite intrusions. The vertical intrusions are called dolorite dykes and the horizontal intrusions dolorite sheets. The Kroonstad Geological map (Geological Survey, 1986) shows no dykes in the vicinity of Lindley but a few dolerite sheets do occur in the area. Contrary to the widespread belief, groundwater in this area does not occur in underground rivers and lakes but is stored in interstices in the rocks as they are formed or in interstices developed after the rocks have consolidated (Bertram, 2013: Interview).

The Kroonstad Hydrogeological Map (DWA, 2000) shows that the Lindley area has a "low groundwater development potential", i.e. $80 \%$ of the boreholes yield small volumes of water (between 0.5 to $2 \mathrm{l} / \mathrm{s}$ [litres per second]). For an interpretation of the issue around "low development potential" see Text Box 1 below:

\section{Text Box 1}

Low development potential (A3, B3, C3 $\mathcal{E} D 3)$ : - enough water for either hand and /or wind pumps, i.e. small supplies for small communities and /or stock watering or single households can easily be achieved. Additional groundwater for community gardening or other poverty alleviation actions will be available. At the high-end of the yield range, larger communities from single boreholes and well fields supplying large communities would be possible. However, due to large variability in borehole yields, an appreciable number of boreholes will have to be drilled to obtain a yield at the highend of the range. Pumping at 2 l/s for 8 hours per day, for 2000 persons, @ 25 l/day can he cunnlied comfortahlv

Source: (Baran, 2000).

The first report on professional groundwater investigations for the water supplies of the town area of Lindley appeared in 1969 (Kok, 1969). The issue was evidently investigated intensively and scrutinised up to 1979 (i.e. Temperley (1970); Kruger and Hofmeyer, (1971); Anon, 1973a; Anon, 1973b; and Leskiewicz (1979)). Throughout these investigations, the surface water option (utilising the Vals River, spruite and rainwater harvesting) was suggested as the feasible and sustainable one (not the investigation and development of groundwater sources). This is probably the reason why the main agricultural activities in the area are stock, cattle- and sheep farming and fairly extensive dry-land cropping. No big-scale irrigation activities from surface- or groundwater are visible on Google Earth images.

Leskiewicz (1979) made two recommendations, i.e. to concentrate primarily on surface water supplies and as a last groundwater possibility, to drill boreholes to depths of between 150 and $200 \mathrm{~m}$ (metres) to possibly strike additional small water bearing fractures. This conclusion is 
also supported by what is shown on the Kroonstad Hydrogeological Map and its interpretation shown in Text Box 1.

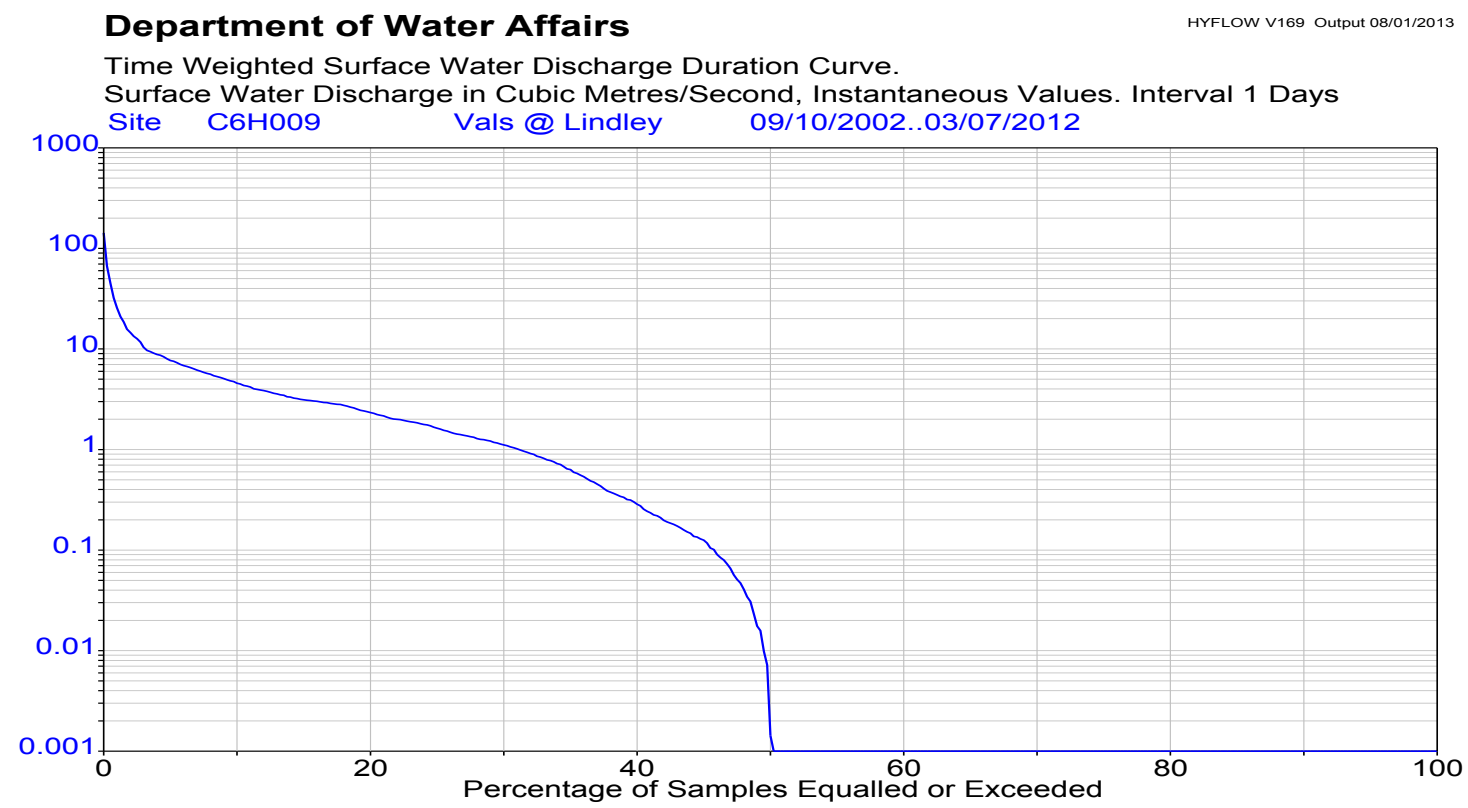

\section{Figure 3: Time-Flow duration curve (Hydstra: 2013a)}

The only possible surface water source in the Lindley area is the Vals River which flows past the town from east to west. The river water-flow characteristics registered at the flow gauging station C6H009 located at Lindley (Vals River: Latitude -27.87250000, Longitude 27.91416667) are shown in Figures 3 and 4. From Figure 3 it can be seen that between 9 October 2012 and 3 July 2012 the river only had water flowing in it 50\% of the time.

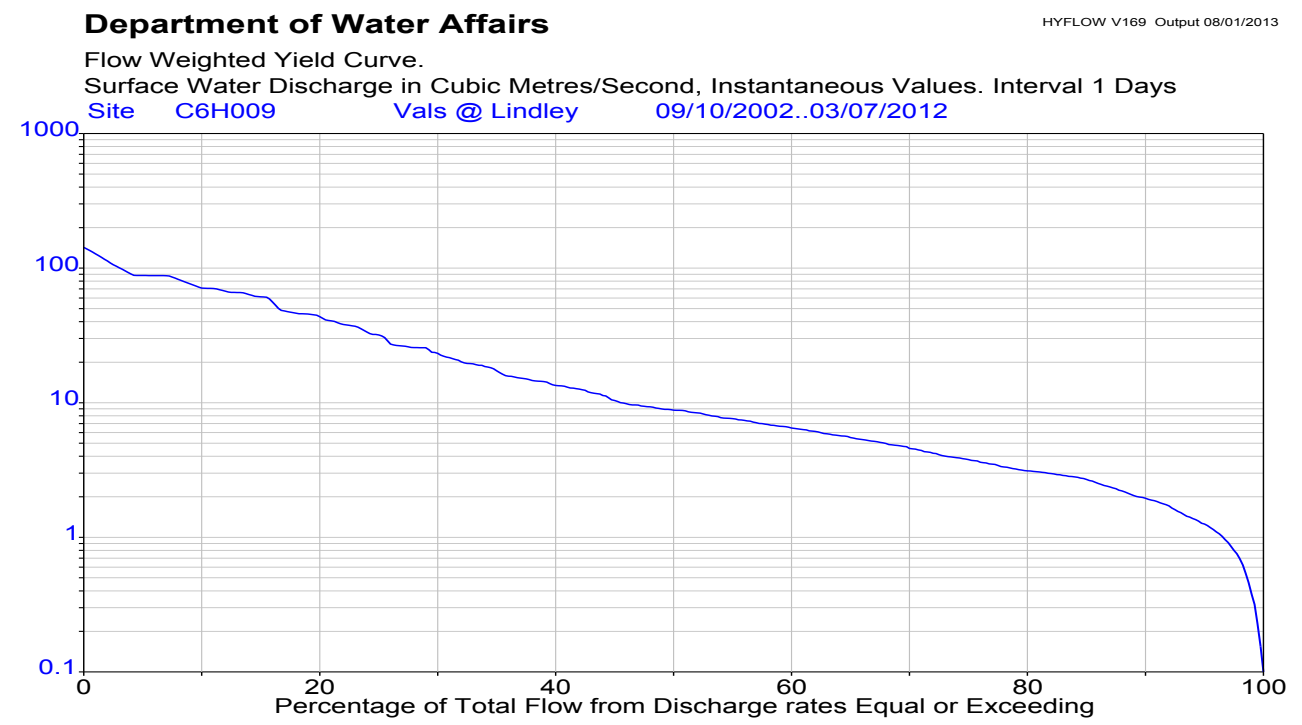

\section{Figure 4: Time-Volume curve (Hydstra: 2013b)}

Figure 4 depicts the flow volumes per time period over the same period registered in Figure 3. From the graph one can see that while the river had some water flowing in it, for almost $80 \%$ of the time, it only flowed at a yield of $3 \mathrm{~m}^{3} /$ second (cubic metre per second). This figure should be evaluated against the water needs of the downstream located towns of Lindley, Steynsrus and Kroonstad. 
The extensive use of off-channel water storage dams (two for Lindley, one for Steynsrus as well as one large dam for Kroonstad) is an indication of the dire need for water along the whole flow trajectory of the Vals River. The capture of water into the off-channel storage dams for Lindley takes place whenever the river flows.

According to the potable water meter readings information obtained from the Water Services Development Plan (2011), the Lindley Town Area's average water consumption in 2011 was $60 \mathrm{Kl} /$ day. This calculates at 20 litres of water / person / day.

Very strict potable water restrictions have been enforced since 1 July 2012 in the Lindley town area to the effect that water is only available in the reticulation network each day between 06:00 to 09:00 and 18:00 to 21:00 (Labuschagne, 2012: Interview).

The costing of the potable water is as follows:

$$
\begin{aligned}
& 0-10 \mathrm{~K} 1=\mathrm{R} 5-56 / \mathrm{K} 1 \\
& 10-15 \mathrm{~K} 1=\mathrm{R} 8-70 / \mathrm{K} 1 \\
& 15-20 \mathrm{~K} 1=\mathrm{R} 11-86 / \mathrm{K} 1
\end{aligned}
$$

(Nketoana Local Municipality, 2013).

According to Labuschagne, there is a revenue collection rate of at least $60 \%$ of all house- and building-stand owners. These exclude theft and loss of potable water as contributor to the level of "unaccounted for water" (UAW) in the Town area (2012: Interview).

During a data collection visit to the Town area the following general facts and impressions were collected from six residents:

- they do not understand the layout and tariff scale of the water billing accounts;

- they do not know or understand the origin of the town's potable water;

- they observe the old town area "dying out" and the new town area expanding fast; and

- they have no knowledge about or understand the destiny of the town's used water.

(Researcher, Aug 2012: Informal interviews).

With reference to Figure 2, the following geo-hydrological, municipal and community development aspects of importance must be noted:

- Approximately 90\% of the Town's potable water is obtained from the surface water abstracted from the Vals River immediately north of the off-channel storage dams (DAM 1 and DAM 2). This usually is possible from January to August of every year. During the remaining months the stored dam water and groundwater abstraction boreholes have to be managed carefully and accurately to ensure that the town residents have access to sufficient quantities and quality of potable water until the subsequent rain season causes sufficient surface water flow in the river.

- In times of river-flow lows, six of the Town's 10 boreholes on the Lindley municipal area (land belonging to the Municipality) are utilised for the potable water supply. All the boreholes are located on the property belonging to the Municipality and not at more suitable locations at a distance from within the geographical municipal area. The following limited geo-hydrological information is available on the 10 boreholes: 


\section{Table 1: Borehole information: Lindley (Labuschagne, 2012: Interview)}

\begin{tabular}{|l|c|l|l|c|}
\hline Number & Depth drilled $(\mathrm{m})$ & $\begin{array}{l}\text { Groundwater rest level } \\
(\mathrm{m})\end{array}$ & Equipment on borehole & $\begin{array}{l}\text { Average yield } \\
\text { (litres/second) }\end{array}$ \\
\hline BH1 & 72 & No data available & Submersible pump & 5.5 \\
\hline BH2 & 62 & No data available & No pump on borehole & 1.8 \\
\hline BH3 & 66 & No data available & Submersible pump & 2.1 \\
\hline BH4 & 61 & No data available & Submersible pump & 2.1 \\
\hline BH5 & 66 & No data available & Submersible pump & 1.9 \\
\hline BH6 & 32 & No data available & No pump (stolen) & 0.7 \\
\hline BH7 & 38 & No data available & No pump (stolen) & 2.2 \\
\hline BH8 & 32 & No data available & No pump (stolen) & 0.8 \\
\hline BH9 & 42 & No data available & Submersible pump & 1.4 \\
\hline BH10 & 38 & No data available & Submersible pump & 4.2 \\
\hline
\end{tabular}

- Bh1 is a borehole fitted with an electric submersible pump inside a manhole ring with cover, protected and pumped for 8 hours per day when the river flow is low. The borehole water is collected at the water purification works where it is submitted to the water treatment process of the Municipality. The security, access, monitoring and sustainability of the important water abstraction point can be improved.

- Bh2 is situated next to the water abstraction point Bh1 and must be used as a groundwater level monitoring point to establish an effective groundwater level record.

- Bh3 and Bh4 are located on the southern bank of the Vals River immediately north of the two off-channel water storage dams. The main river water abstraction point from the river is also located here.

- The Water Purification Works is situated at the small dam wall (weir) built next to the old bridge (north of Bh5).

- The safety and security aspects of ALL the potable water abstraction boreholes of the Municipality need attention and must be addressed as soon as possible.

- Groundwater levels, and quantities abstracted must be monitored and reported on at all the abstraction sites.

- The location of the Town's main cemetery immediately up-stream of the two Off Channel Storage Dams (DAM1 and DAM 2) as a potential polluter is a point of concern and must be investigated.

- The safety and security aspects (i.e. visibility, access and impact on physical and manchanged environment) of the water storage dams DAM 1 and DAM 2, Water Purification Works (and the newly constructed one), water storage reservoirs at RES1 and RES2, as well as the SW1 Sewage Works should be investigated, upgraded and managed to the expectations of DWA to comply with the Blue Drop as well as the Green Drop assessment standards.

- The refuse dump site right at the southern entrance to the Town is a blot on the landscape and possible polluter of the groundwater abstracted at boreholes Bh8, Bh9 and specifically Bh10 (where town residents can fetch drinking water in times of severe water shortage), and should be relocated. 
- Tourism potential of the Town (i.e. history, river location, caravan park and guest houses on the main route from Kroonstad to Bethlehem) must be investigated and catered for.

\section{Conclusion}

On the basis of this research and for various reasons (e.g. diminishing volumes and qualities of safe potable water, climate change and the more sophisticated needs of millions more citizens), the researchers argue that the effective municipal management of water related basic services in the developing South Africa entails highly complex hydrological, geo-hydrological and municipal management functions in a dynamic and highly regulated environment. It requires the municipal managers, officials and political office-bearers of a municipality to be equipped with specific knowledge and skills regarding the physical environment and management of basic water related public services.

On the basis of this research and for various obvious reasons (e.g. deteriorating physical environment due to pollution, sub-standard storm water and sewage management, migration [informal settlements] and the increasingly sophisticated needs of municipal residents), the researchers are of the opinion that the level of co-operative governance and integrated water resources management (IWRM) in the whole Vals River catchment is very low.

Groundwater and surface water reserves on the current utilised municipality property in and around Lindley are unsustainable for a growing Lindley community with sophisticated needs and incorporation of improved potable water supply, new sanitation, and, for example, washing (solar geysers) infrastructures. The locations of the municipal boreholes drilled and equipped in the past reflect the reigning paradigm that groundwater should be found within the town allotment area; that is, the water should be found where it is needed and not where it may possibly occur geo-hydrologically.

\section{Recommendations}

More effective trans-boundary municipal management through simunye-type co-operative governance and IWRM must be facilitated in the Vals River surface water catchment between the respective local and district municipalities for the benefit of the Lindley, Arlington, Steynsrus and Kroonstad communities. The service providers in the area deserve and need assistance from neighbouring municipalities and regulatory provincial and national government service rendering institutions (e.g. DWA and the Department of Co-operative Governance and Traditional Affairs (CoGTA).

Although the groundwater potential in the Lindley area is very low, it seems prudent to consider carrying out a professional geo-hydrological investigation by an accredited groundwater specialist to prove beyond any reasonable doubt that groundwater is not an option in the Town- as well as the immediate surrounding area. Should such an investigation with its subsequent exploration drilling fail, it is clear that the surface water supply for Lindley and its fast growing population should be augmented by other means.

More water must be identified, developed and brought into the area. In other words, the Vals River must become sustainable in that additional surface water can be added into the catchment for the three towns along its flow down to the Vaal River at Bothaville. Linking the origin of the Vals River and the Lesotho Highlands water via the As River near Clarens is a possibility that should be investigated. 
Land- and river use must also be determined and regulated along the natural flow of the Vals River to ascertain the extent of water reserves available for use and consumption by the downstream located water-poor towns of Lindley, Steynsrus and Kroonstad.

The possibility of importing potable water from the water-rich Bethlehem area via the current out of commission oil pipeline that passes south of Lindley and north of Arlington and Steynsrus, should be seriously considered.

\section{List of courses}

Anon. 1973a. Lindley Munisipaliteit, Welman 858 boorplekaanwysings. Unpublished report Gh1820. Pretoria: Department of Mines, Geological Survey.

Anon. 1973b. Bepaling van die porositeit van die dolerietgang te Lindley. Unpublished report Gh1825. Pretoria: Department of Mines, Geological Survey.

Baran. 2000. Kroonstad Hydrogeological Map and brochure.

Bertram, E. 2013. Interview between the Deputy-Director, Geo-hydrology, DWA / Prof EJ Nealer (Researcher), 4 August 2013.

Brits, F. 2012. Personal interview with Steynsrus town office manager on 15 August 2012.

Department of Housing (Free State Province). 2012. Memo to Lindley Town office. DoH.

Department of Land Affairs. 1987. 1:50 000 scale Topographical map 2727 DD Lindley. Cape Town: Government Printer.

Department of Water Affairs and Forestry (DWAF). 2005. Masibambane water service sector support programme in the Free State Province. Available at: www.dwaf.gov.za/masibambane/documents/strategies/pwsp/fs.pdf Accessed on 19 October 2013.

Fuggle, R.F. \& Rabie, M.A. 2005. Environmental management in South Africa. Cape Town: Juta \& Co, Ltd.

Geological Survey. 1986. 1:250 0002726 Kroonstad Geological map. Pretoria: Geological Survey.

Glasson, J. \& Wood, G. 2009. Urban regeneration and impact assessment for social sustainability. Impact Assessment and Project Appraisal, 27(4), December 2009.

GPM Consultants. 2012. Topographical map of the Vals River catchment and respective municipalities. Polokwane: GPM.

Hydstra, 2013a \& b. The Department of Water Affairs' Flow data database - graphs kindly reproduced by Directorate: Hydrological Services staff member. Pretoria: DWA.

Interviews with three officials of the Lindley town office. 13 August 2012.

Kok, T.S. 1969. Beskikbare inligting oor watervoorsiening by Heilbron, Lindley, Petrussteyn, Edenville en Steynsrus. Unpublished report Gh1587. Pretoria: Department of Mines, Geological Survey.

Kruger, J.C. \& Hofmeyer, S. 1971. Lindley Munisipaliteit: Voorlopige verslag oor boorplekaanwysings. Unpublished report Gh1739. Pretoria: Department of Mines, Geological Survey. 
Labuschagne, A. 2012. Personal interview with Lindley town office manager on 13 August 2012.

Leskiewicz, A.F. 1979. Geohydrology of Lindley Area - as revised by Leskiewicz. Unpublished report Gh3139. Pretoria: Department of Mines, Geological Survey.

Lindley. 2007. Available at: http://www.co.za/history. Accessed on 16 July 2014.

Nealer, E.J. \& Naudé, M. 2011. Integrated co-operative governance in the context of sustainable development. The Journal for Trans-disciplinary Research in Southern Africa. 7(1) July 2011 pp. 195-217.

Nketoana Local Municipality. 2013. Tariff list. Reitz.

Republic of South Africa (RSA). 1998. Local Government: Municipal Demarcation Act 27 of 1998. Pretoria: Government Printer.

SACS, 1980. Republic of South Africa, Geological Survey. STRATIGRAPHY OF SOUTH AFRICA. Handbook 8. Part 1: Lithostratigraphy of the Republic of South Africa, South West Africa/Namibia and the Republics of Bophuthatswana, Transkei and Venda.

Temperley, B.N. 1970. Aquifer air cover survey - sheet 2727DD Lindley. Unpublished report Gh1540. Pretoria: Department of Mines, Geological Survey.

Thompson, H. 2006. Water law: A practical approach to resource management $\mathcal{E}$ the provision of services. Cape Town: Juta \& Co, Ltd.

Van der Waldt, G., Khalo, T., Nealer, E.J., Phutiagae, K., Van der walt, C., Van Niekerk, D. \& Venter, A. 2014. Municipal Management: Serving the people. Claremont: Juta and Company Ltd. 